\title{
Cytogenetic and blood group studies of sheep/goat chimaeras
}

\author{
C. B. Fehilly, S. M. Willadsen, A. R. Dain and E. M. Tucker \\ AFRC Institute of Animal Physiology, Babraham, Cambridge CB2 4AT, U.K.
}

\begin{abstract}
Summary. Aggregation chimaeras were composed of quarter (or 1 cell) contributions from 4-cell blastocysts of sheep or goats, or of an 8-cell blastocyst of one species enveloped in three 8-cell blastocysts of the other. Gestation was in sheep or goat recipient females. Of the 10 living animals born, 3 were identified as interspecific chimaeras by body conformation and coat type among the 7 quarter/quarter aggregations and 1 among the 3 giant aggregates. Interspecific chimaerism was identified by cytogenetic study of umbilicus and blood lymphocytes respectively of 2 of these, one from each type of aggregate. Intraspecific sex chimaerism was found in 3 other animals; 2 were of giant aggregate origin, but the 1 of quarter/quarter origin must have acquired it by placental anastomosis with a twin conceptus. Tests using speciesspecific monoclonal antibodies and electrophoretic separation of haemoglobins and isoenzymes demonstrated sheep and goat erythrocytes in one giant aggregate chimaera; their relative proportions and those of the blood lymphocytes changed over a period of 31 months from approximately $60 \%$ goat and $40 \%$ sheep to more than $90 \%$ sheep. The plasma transferrins and amylases did not show similar relative changes from their predominantly goat-like character and, by implication, neither did their tissues of origin.
\end{abstract}

\section{Introduction}

There is a family relationship between the two genera, Ovis and Capra, but hybridization is extremely rare (Steven \& Morriss, 1975; Bunch, Foote \& Spillett, 1976) and no living hybrid fetus has been carried to term in a controlled experiment in a sheep or a goat. Instead, there is a catastrophic hybrid mortality in the 2 nd month of pregnancy, which may be due to immunological incompatibility between the conceptus and the uterine environment (Dent, McGovern \& Hancock, 1971). In the ruminant uterus the potential sites of placentation (the caruncles) probably combine with whichever part of the embryonic chorion is in contact with them at the time of placental initiation (King, Atkinson \& Robertson, 1982). The mosaic distribution of cells of both species in the chorion of chimaeric embryos may be such that placentomes are then formed by maternal and fetal tissues of the same species. Although some placentomes may fail, due to incompatibility, it is likely that the hypertrophy of others in which compatibility has been established could maintain the pregnancy (as in twin conceptuses when there are fewer placentomes).

Successful sheep/sheep chimaeras had already been produced (Tucker, Moor \& Rowson, 1974; Tucker, Dain \& Moor, 1978; Fehilly, Willadseı \& Tucker, 1984a) when attempts, based on these experiences were made to produce sheep/goat chimaeras by combining single cells from 4-cell embryos of both species. An attempt was then made, also by the aggregation method, to produce chimaeric embryos in such a way that the chorion consisted of cells belonging to the species of the recipient female. In this second series giant embryos were produced by surrounding the 8-cell embryo of one species with the disaggregated blastomeres of three 8 -cell embryos of the other 
species. The anatomical and blood group results of these experiments have been reported elsewhere (Fehilly et al., 1984b); 26 offspring were described, 14 of which were 'sheep-like', 4 'goat-like' and 8 were identified as sheep/goat chimaeras. The present paper adds details of the cytogenetic work which was done on some of these animals as well as the blood group studies. The sheep and the goat tissues were readily distinguished by chromosomal analysis and by differences in red cell antigens and in electrophoretic properties of certain proteins (Tucker \& Clarke, 1980).

\section{Materials and Methods}

The animals which were the subjects of the present study were produced in the course of experiments which have been described elsewhere (Fehilly et al., 1984b).

Blood collection. Heparinized samples were collected from the animals at various times after birth.

Cytogenetics. Blood lymphocytes were prepared from whole blood within 18 days of birth by a modification of the method of Basrur \& Gilman (1964). The umbilical cord cells were prepared from monolayer cultures of cord cells at Caesarian section. Transverse sections of the cords were taken immediately after birth at the point where they were tied at Caesarian delivery. The tissue was chopped finely and cultured in RPMI 1640 medium with $10 \%$ fetal calf serum and antibiotics. Chromosome preparations were made on the 11 th day of culture. The monolayers were treated with colcemid in situ to arrest spindle formation; the cells were scraped from the flasks and chromosome spreads prepared by the standard hypotonic treatment followed by fixation, spreading on glass slides and Giemsa staining.

From each chromosome preparation 25 cells were analysed with the exception of $\mathrm{Kid} 10$ for which 15 cells were examined.

Identification of sheep and goat blood types. Sheep and goat red-cell antigens were identified in a haemolytic test using mouse monoclonal antibodies which are specific for sheep $\left(\mathrm{F}_{2} \mathrm{~A}_{2}\right)$ and goat (AA5) red cells (Tucker, Wright \& Varden, 1981). These antibodies were also used to separate the two populations of red cells from the chimaeric admixture by differential haemolysis (Dain \& Tucker, 1970; Tucker et al., 1974).

Electrophoretic separations of sheep and goat plasma transferrins and amylases and of the redcell enzymes NADH-diaphorase, nucleoside phosphorylase and superoxide dismutase were performed on starch gels as described previously (Tucker \& Clarke, 1980). Haemoglobin types were distinguished by isoelectric focussing in agarose gels over a $\mathrm{pH}$ range 5-8 (Tucker, Clarke, Osterhoff \& Groenewald, 1983). Red-cell potassium concentrations were determined by flame photometry to identify LK (low potassium) and HK (high potassium) genetic types (Tucker et al., 1974), and red-cell size distribution was determined in a Fluorescence Activated Cell Sorter (FACS: Becton Dickinson, Sunnyvale, CA 94086, U.S.A.).

\section{Results}

\section{Morphology and cytogenetics}

Table 1 shows that 5 of the 10 live-born offspring from the 3 types of aggregation showed cytogenetic chimaerism. Two of these were interspecific sheep/goat chimaeras and the remainder were intraspecific. The chromosomes of cultured umbilical cells confirmed interspecific chimaerism in one neonate (No. 1) among the live-born offspring from aggregation between single cells from 4-cell embryos of sheep and goats. This animal, which had the general appearance of a lamb but had bands and patches of hair in the woolly fleece, contained $72 \%$ normal female sheep cells and $28 \%$ normal male goat cells in the umbilicus (Table 1). There was no overt abnormality of 


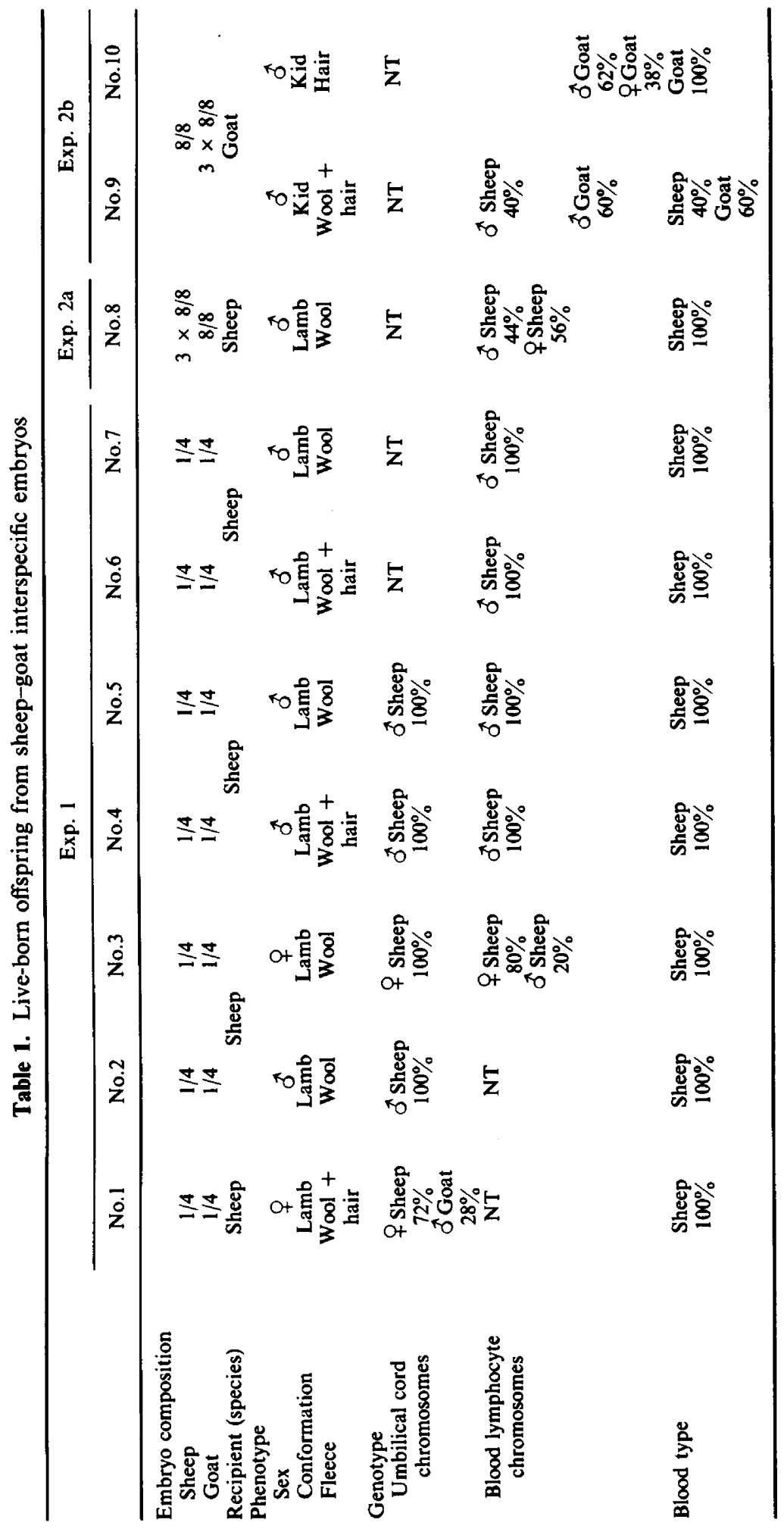


the reproductive organs, which were female, and no abnormality was seen in the reproductive organs at autopsy, but histological observations were not made. The blood lymphocytes were not examined since this lamb died before a suitable sample had been taken. The chromosomal examination also revealed one intraspecific reticuloendothelial chimaera in this group, No. 3, which had sex chimaerism of the sheep lymphocytes of the blood; they were $80 \%$ female and $20 \%$ male. Her chimaerism was only found in these reticulo-endothelial cells; she showed $100 \%$ sheep cells in the umbilicus and there were no overt signs of interspecific chimaerism. In this case the recipient ewe had carried twins and the co-twin, No. 2, was a male lamb which had $100 \%$ male sheep cells in the umbilicus. The latter lamb died within $72 \mathrm{~h}$ of birth and his blood lymphocytes were not examined. Both tissues were examined in the twin pair of male lambs, Nos 4 and 5, but neither inter- nor intraspecific chimaerism was found. All cells had the male sheep genotype. In spite of this, overt wool/hair chimaerism of the fleece was clear in No. 4, which was therefore judged an interspecific chimaera. Male blood lymphocytes only were found in Nos 6 and 7. The umbilicus was not examined in these 2 male lambs, but No. 6 had a chimaeric fleece in which the wool was interspersed with transverse bands of hair originating asymmetrically in the dorsal midline; it also had other hairy patches. This animal was therefore judged to be an interspecific chimaera on the grounds of its coat alone.

All 3 living products of Exps $2 a$ and $2 b$ showed cytogenetic chimaerism. One (No. 9) was a sheep/goat chimaera in which both specific components had a male genotype. He was born to a goat recipient and was the product of 3 goat embryos aggregated with one sheep embryo. At 2 weeks of age, the blood lymphocytes were $40 \%$ male sheep genotype and $60 \%$ goat genotype. The coat contained both wool and hair. At 31 months the proportion of sheep and goat cells in the cultured blood lymphocytes had altered to $96 \%$ and $4 \%$ respectively. The other product of the same pregnancy was an apparently normal male kid, which nevertheless had intraspecific sex chimaerism of the blood lymphocytes: these were $62 \%$ male goat and $38 \%$ female goat. The third living product of the giant aggregation embryos (No. 8) was from Exp. 2a, in which the sheep recipient carried an aggregation of one goat embryo and 3 sheep embryos. It was a male lamb with intraspecific sex chimaerism of the blood lymphocytes which were $44 \%$ male sheep and $56 \%$ female sheep.

\section{Blood typing}

Blood samples from all presumptive chimaeras were tested close to the time of birth and at intervals thereafter. All the overt chimaeras had a blood type that could only be ascribed to sheep except for No. 9 in which clear signs of blood chimaerism were apparent. The remaining animals had blood characteristics entirely of the type corresponding to their species of physical appearance. The blood of No. 9 was studied in some detail, as described below.

\section{Red-cell antigens}

Partial haemolysis, indicating the presence of two populations of cells, was seen when the erythrocytes from chimaera No. 9 were tested with the species-specific monoclonal antibodies, $\mathrm{F}_{2} \mathrm{~A}_{2}$ and AA5. Differential haemolysis tests permitted determination of the relative proportions of the sheep and goat red cells. At 2 weeks and 4 months after birth there were respectively $68 \%$ and $67 \%$ goat red cells present. By 11 months goat red cells had fallen to $35 \%$, and by 31 months there were only about $8 \%$ of goat red cells present. Measurement of red cell potassium concentration after differential haemolysis with antibodies $\mathrm{F}_{2} \mathrm{~A}_{2}$ and $\mathrm{AA} 5$ showed that sheep and goat red cells were respectively LK (low potassium) and HK (high potassium) genetic types, thus providing further evidence of the presence of two distinct populations of cells. 

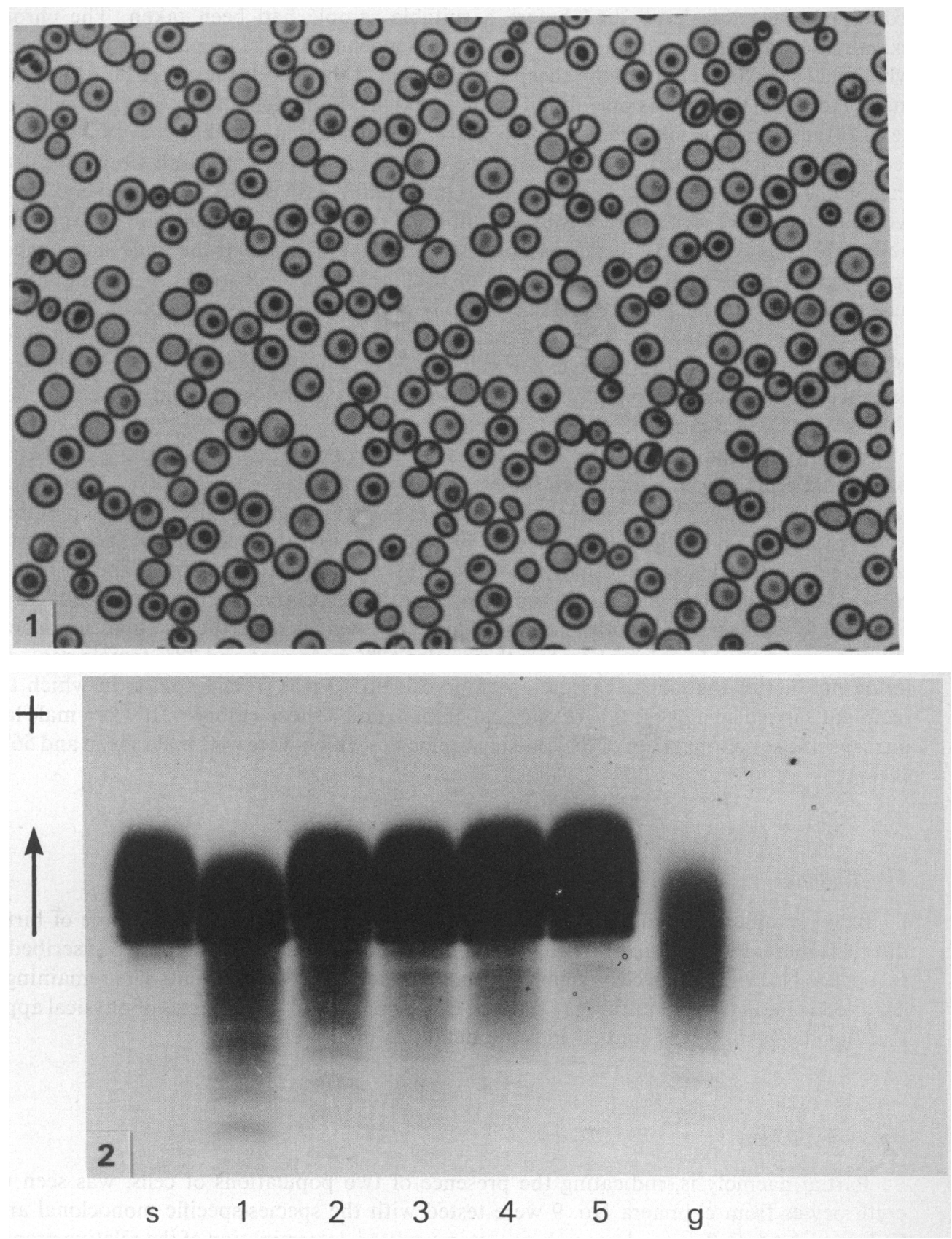

Fig. 1. Blood film from chimaera No. 9. Leishman stain, $\times 22400$.

Fig. 2. Age-related changes in red cell nucleoside phosphorylase (NP) isoenzyme patterns in chimaera No. 9. Starch gel electrophoresis at $\mathrm{pH} 7 \cdot 2$. ' $\mathrm{s}$ ' and ' $\mathrm{g}$ ' are the normal sheep and goat patterns respectively, for the isoenzymes. Samples 1, 2, 3, 4 and 5 were taken at 2 weeks, 4 months, 8 months, 11 months and 31 months of age, respectively. 
PLATE 2

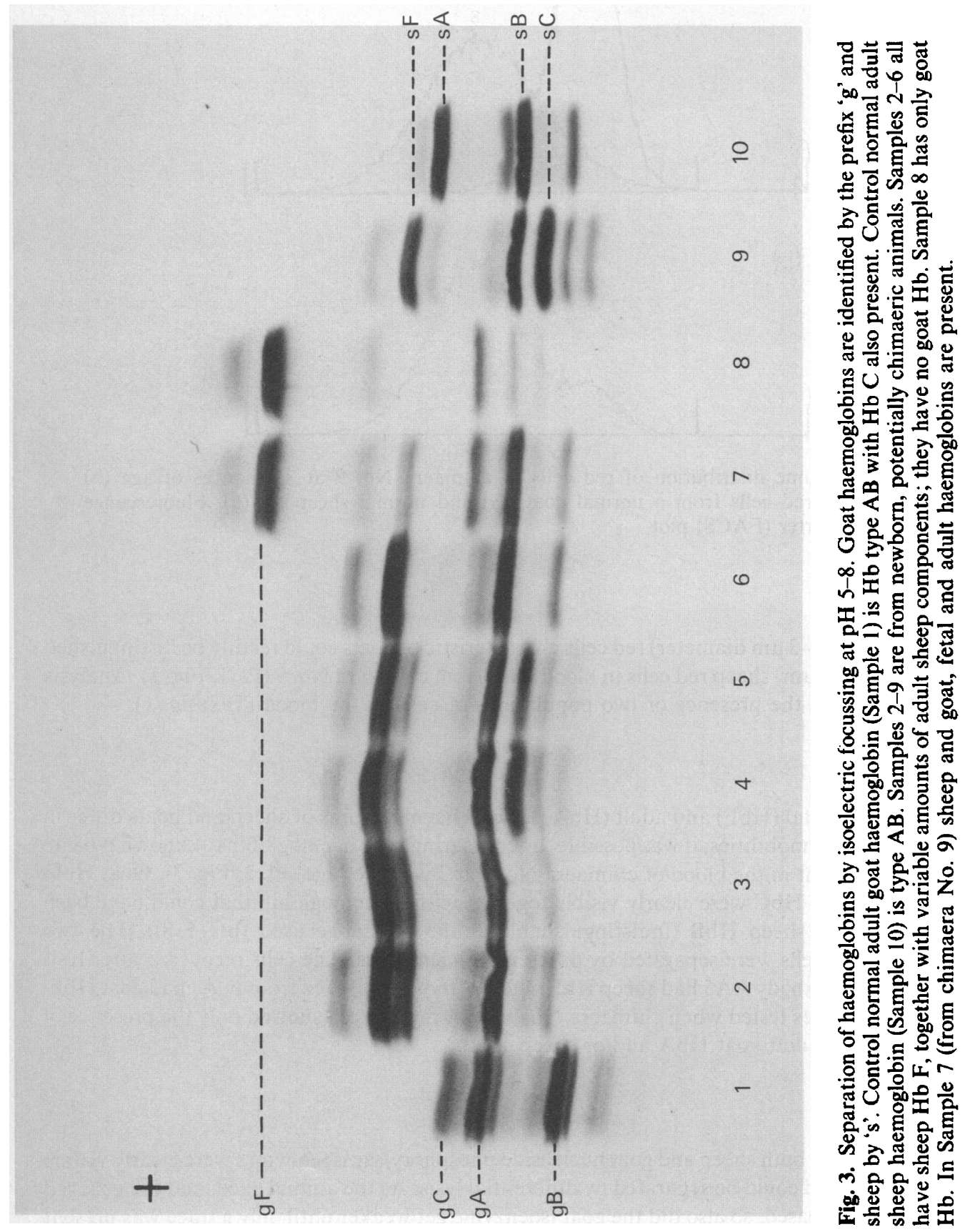



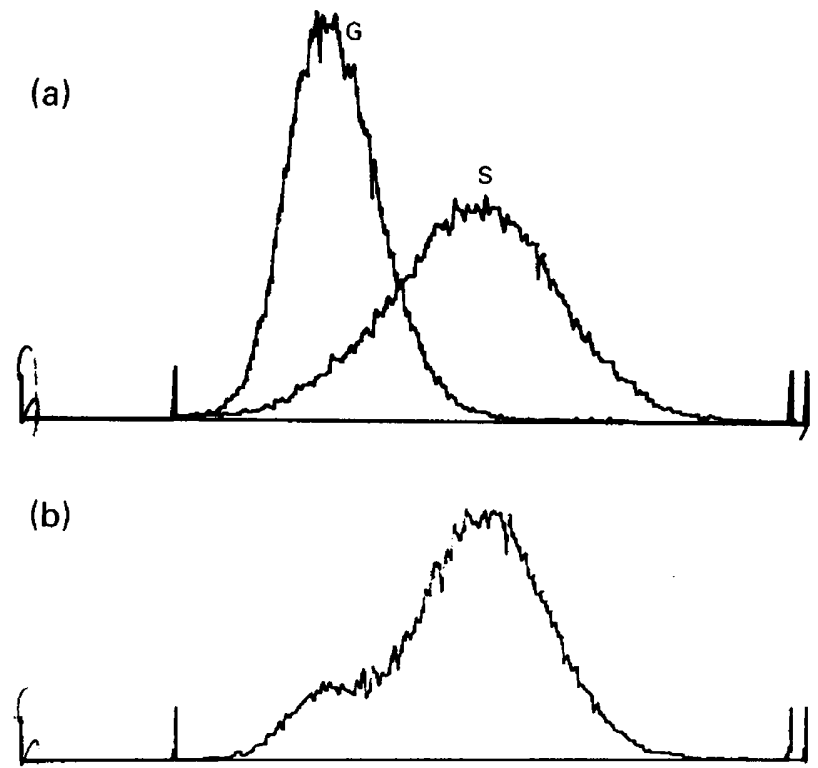

Text-fig. 1. Volume distribution of red cells of chimaera No. 9 at 31 months of age (b) compared with red cells from a normal goat (G) and normal sheep (S) (a). Fluorescence activated cell sorter (FACS) plot.

\section{Red-cell morphology}

The very small ( $\sim 3 \mu \mathrm{m}$ diameter) red cells characteristic of goats could readily be distinguished from the larger $(4-5 \mu \mathrm{m})$ sheep red cells in blood films from chimaera No. 9 (Pl. 1, Fig. 1). Analysis by FACS confirmed the presence of two populations of cells in the blood (Text-fig. 1).

\section{Haemoglobin types}

Since both the fetal (HbF) and adult (HbA, B or C) haemoglobins of sheep and goats differ in their electrophoretic mobilities, it was possible, by comparing with haemoglobins of known type, to identify those present in the blood of chimaera No. 9 at 2 weeks of age (Pl. 2, Fig. 3). Goat HbF, sheep $\mathrm{HbF}$ and goat $\mathrm{HbC}$ were clearly visible together with a haemoglobin that could have been adult goat $\mathrm{HbA}$ or sheep $\mathrm{HbB}$ (indistinguishable at the $\mathrm{pH}$ range used $(\mathrm{pH} \mathrm{5-8)}$ ). The two populations of red cells were separated by differential haemolysis. The cells recovered after lysis with monoclonal antibody $A A 5$ had sheep $\mathrm{HbF}$ whereas those recovered from $\mathrm{F}_{2} \mathrm{~A}_{2}$ had goat $\mathrm{HbF}$. Haemoglobin samples tested when chimaera No. 9 was 4 months old showed only the presence of goat $\mathrm{HbC}$ and the adult goat $\mathrm{HbA}$ and/or sheep $\mathrm{HbB}$.

\section{Red-cell enzymes}

At 2 weeks of age both sheep and goat nucleoside phosphorylase isoenzymes were clearly visible in red cell lysates and could be separated by differential lysis. As the animal aged, and the goat red cell population decreased, so also did the goat isoenzyme get weaker until only a trace was present at 31 months (Pl. 1, Fig. 2).

Goat and sheep NADH-diaphorase, superoxide dismutase isoenzymes and ' $\mathrm{X}$ ' protein were also seen in red-cell lysates taken soon after birth, and the goat isoenzymes became weaker as the animal aged. 


\section{Plasma transferrins and amylases}

The major transferrin (Tf) in chimaera No. 9 was goat Tf A with only trace amounts of sheep Tf A which is electrophoretically 'faster' on starch gels than goat Tf A. In contrast to the red cells, there was no evidence of change in the relative proportions of the transferrins as the animal aged. The same was true of the plasma amylases which were predominantly goat-like and remained so.

\section{Discussion}

The offspring from embryos which were sheep-goat chimaeras showed various degrees of chimaerism. The interspecific chimaerism of the blood lymphocytes, red cells, and plasma transferrins and amylases shows that the chimaerism can exist in cells of mesodermal and endodermal origin. Although both the lymphocytes and red cells were predominantly goat type in chimaera No. 9 at birth $(60 \%$ goat : $40 \%$ sheep), the proportions changed as the animal aged until at $2 \frac{1}{2}$ years there were $<10 \%$ goat cells left. The plasma remained predominantly goat-like throughout. These findings are similar to those found in sheep/sheep chimaeras (Tucker et al., 1978) and the most likely explanation of the change is that there is a selective fitness of one cell type over another. In allophenic mice Mintz \& Palm (1969) suggested a possible selective advantage of C56BL/6 over $\mathrm{C} 3 \mathrm{H}$ mouse erythropoietic tissues. In naturally occurring chimaerism, caused by placental anastomosis, there have been various reports of changes of red cell populations with age. In human (Race \& Sanger, 1968) and cattle (Stone, Friedman \& Fregin, 1964) chimaeras changes were observed, but Dain \& Tucker (1970) found no change in the red cell populations of sheep chimaeras. The lymphocyte populations of 5 pairs of chimaeric twin sheep, however, changed slowly over a period of several years, during which the two cell populations showed the same bias in both twins (Dain, 1974). A similar tendency to the establishment of one cell type over another has been described in chromosome mosaicism in the zebra (Whitehouse, Evans, George \& Putt, 1985). In chimaera No. 1 the umbilical chimaerism may have been due to tissues originating from the endoderm, mesoderm or both, but in any case it bears out, as do the chimaeric coats of some of the animals, the functional integration of interspecific chimaeric tissues.

It may be relevant that the live-born offspring which developed from the chimaeric embryos were biased, both in conformation and in genotype, towards the species of their recipient 'mother'. This may be explained by the observations of Fehilly et al. (1984b) and Meineke-Tillmann \& Meineke (1984) that it is possible to overcome the reproductive barrier between sheep and goats when there is a protective mechanism (chorionic epithelium) which prevents recognition of the foreign fetus by the mother. Of the 8 live offspring which developed from chimaeric embryos in recipient ewes, all had either $100 \%$ sheep chromosomes in the tissues examined and $100 \%$ sheep red cells, or (as in No. 1 of the 3 interspecific chimaeric lambs Nos 1, 4 and 6) had a greater proportion $(72 \%)$ of sheep than goat chromosomes in umbilical cells. The intraspecific chimaera No. 8 , had both male and female sheep cells in the blood lymphocytes. These must have represented 2 and possibly all 3 of the original sheep embryos, while goat chromosomes were not found. These findings, together with the lamb-like conformation of all 8 animals, suggest that the goat components of these embryos were attenuated or missing. This pattern was repeated in the living offspring of the single goat recipient which is reported here: the $60 \%$ male goat cells in the blood lymphocytes of the interspecific chimaera No. 9 and the $100 \%$ goat cells in the lymphocytes from No. 10, combine with the evidence of the body conformation and the exclusively goat-like features of the blood in No. 10, to point to the possibility of selection against the sheep components of these embryos in utero. Placental anastomosis between Nos 9 and 10 is unlikely to explain the sex chimaerism of the blood of the intraspecific chimaera No. 10 since male cells which cross the placenta to populate the bone marrow of female co-twins do not result in normal masculinization of the external genitalia. The normal male genitalia of chimaera No. 10 were therefore induced by an original male clone, while the female goat component is unlikely to have come from No. 9, whose 
lymphocyte chromosomes were found to be exclusively male. Accordingly, this tissue indicates survival of at least 2 of the original goat embryos while the sheep component was not detected in No. 10. Conversely, placental anastomosis is the probable explanation of the reticuloendothelial chimaerism of lamb No. 3. Her male sheep cells must have crossed the placenta from her male cotwin, since only one sheep embryo (the female one) was involved in the original aggregation.

The low incidence of interspecific chimaerism, together with the demonstrated bias of genotype and phenotype towards the species of the recipient, probably indicates a reaction by the recipient against cells of another species. The successful production of chimaerism may have been assisted by the neutralizing effect of the construction of the giant embryos, which were designed to present the recipient with a chimaeric embryo wrapped in cells of her own species (Fehilly et al., 1984b; Meineke-Tillman \& Meineke, 1984). This possibility indicates practical applications of the findings.

We thank Mr N. G. A. Miller for the FACS analyses, and Mr L. Kilgour and Miss S. W. Clarke for technical assistance.

\section{References}

Basrur, P.K. \& Gilman, J.P.W. (1964) Blood culture method for the study of bovine chromosomes. Nature, Lond. 204, 1335.

Bunch, T.D., Foote, W.C. \& Spillett, J.J. (1976) Sheepgoat hybrid karyotypes. Theriogenology 6, 379-385.

Dain, A.R. (1974) A study of the proportions of male and female leucocytes in the blood of chimaeric sheep. $J$. Anat. 118, 53-59.

Dain, A.R. \& Tucker, E.M. (1970) Cytogenetic, anatomical and blood group studies of sheep twin chimaeras. Proc. R. Soc. Lond. B 175, 183-200.

Dent, J., McGovern, P.T. \& Hancock, J.L. (1971) Immunological implications of ultrastructural studies of goat $\times$ sheep hybrid placentae. Nature, Lond. 231, $116-117$.

Fehilly, C.B., Willadsen, S.M. \& Tucker, E.M. (1984a) Experimental chimaerism in sheep. J. Reprod. Fert. 70, 347-351.

Fehilly, C.B., Willadsen, S.M. \& Tucker, E.M. (1984b) Interspecific chimaerism between sheep and goat. Nature, Lond. 307, 634-636.

King, G.J., Atkinson, B.A. \& Robertson, H.A. (1982) Implantation and early placentation in domestic ungulates. J. Reprod. Fert. 31, 17-30.

Meineke-Tillman, S. \& Meineke, B. (1984) Experimental chimaeras; removal of reproductive barrier between sheep and goat. Nature, Lond. 307, 637-638.

Mintz, B. \& Palm, J. (1969) Gene control of haematopoiesis. 1. Erythrocyte mosaicism and permanent immunological tolerance in allophenic mice. $J$. exp. Med. 129, 1013-1025.

Race, R.R. \& Sanger, R. (1968) Blood groups in Man, 5th edn, p. 475. Blackwell Scientific Publications, Oxford.
Steven, D. \& Morriss, G. (1975) Development of the foetal membranes. In Comparative Placentation, pp. 58-85. Ed. D. H. Steven. Academic Press, London.

Stone, W.H., Friedman, J. \& Fregin, A. (1964) Possible somatic cell mating in twin cattle with erythrocyte mosaicism. Proc. natn. Acad. Sci. U.S.A. 51, 10361043.

Tucker, E.M. \& Clarke, S.W. (1980) Comparative aspects of biochemical polymorphism in the blood of Caprinae species and their hybrids. Anim. Blood Grps biochem. Genet. 11, 163-183.

Tucker, E.M., Moor, R.M. \& Rowson, L.E.A. (1974) Tetraparental sheep chimaeras induced by blastomere transplantation. Changes in blood type with age. Immunology 26, 613-621.

Tucker, E.M., Dain, A.R. \& Moor, R.M. (1978) Sex chromosome chimaerism and the transmission of blood group genes by tetraparental rams. J. Reprod. Fert. 54, 77-83.

Tucker, E.M., Wright, L.J. \& Varden, S.E. (1981) Monoclonal antibodies to blood group antigens on ruminant red cells. Immunology Letters 3, 121-123.

Tucker, E.M., Clarke, S.W., Osterhoff, D.R. \& Groenewald, J. (1983) An investigation of five genetic loci controlling polymorphic variants in the red cells of goats. Anim. Blood Grps biochem. Genet. 14, 269 277.

Whitehouse, D.B., Evans, E.P., George, A.M. \& Putt, W. (1985) Chromosome mosaicism in a zebra (Equus burchelli) abortus provides evidence for a different invivo/in-vitro survival of balanced and unbalanced karyotypes. J. Reprod. Fert. 73, 401-403.

Received 12 September 1984 